\title{
Oceanotoga teriensis gen. nov., sp. nov., a thermophilic bacterium isolated from offshore oil-producing wells
}

\author{
Himali S. Jayasinghearachchi and Banwari Lal \\ The Energy and Resource Institute, Darbari Seth Block, Habitat Place, Lodhi Road, \\ New Delhi - 110 003, India
}

Correspondence

Banwari Lal

banwaril@teri.res.in
Petroleum reservoirs constitute a group of unique sites with respect to their physico-chemical conditions (halophilic and thermophilic) and provide ecological niches from which taxonomically, physiologically and phylogenetically unusual microbes can be isolated (Bhupathiraju et al., 1993; Ravot et al., 1995; Fardeau et al., 1997). Members of the order Thermotogales, first described as an order containing hyperthermophilic bacteria, have been isolated from extreme environments such as deep-sea hydrothermal vents, hot springs, continental and subcontinental volcanic areas, marine sediments and oil reservoirs (Nunoura et al., 2007; Alain et al., 2002; Huber \& Stetter, 1992; Davey et al., 1993).

Within the order Thermotogales, the genera Thermotoga (Huber et al., 1986), Thermosipho (Huber et al., 1989), Fervidobacterium (Patel et al., 1985), Petrotoga and Geotoga (Davey et al., 1993), Marinitoga (Wery et al., 2001), Kosmotoga (DiPippo et al., 2009) and Thermococcoides (Feng et al., 2010) have been described. Representatives of these genera are anaerobic, chemo-organotrophic, thermophilic, Gram-negative, non-sporulating, rod-shaped bacteria that are characterized by a sheath-like outer structure called the 'toga' (Huber et al., 1986). In this study, a novel strain of moderately thermophilic bacteria is described that

The GenBank/EMBL/DDBJ accession number for the 16S rRNA gene sequence of Oceanotoga teriensis OCT74 ${ }^{\top}$ is EU588727. was isolated from offshore oil-producing well heads located at Bombay High (Western India).

Formation fluid samples were collected from oil-well heads into $50 \mathrm{ml}$ anaerobic sterilized serum bottles containing sodium sulfide at a final concentration of $20 \mathrm{mM}$. Samples were transported to the laboratory under ambient conditions. Collection of samples was performed from December 2007 to January 2008.

A basal medium composed of $\left(1^{-1}\right.$ deionized water $): 1 \mathrm{~g}$ $\mathrm{NH}_{4} \mathrm{Cl}_{2}, 0.3 \mathrm{~g} \mathrm{~K}_{2} \mathrm{HPO}_{4}, 0.3 \mathrm{~g} \mathrm{KH}_{2} \mathrm{PO}_{4}, 0.2 \mathrm{~g} \mathrm{MgCl}_{2} .6 \mathrm{H}_{2} \mathrm{O}$, $0.1 \mathrm{~g} \mathrm{CaCl} 2.2 \mathrm{H}_{2} \mathrm{O}, \quad 10.0 \mathrm{~g} \mathrm{NaCl}, 0.1 \mathrm{~g} \quad \mathrm{KCl}, \quad 0.5 \mathrm{~g}$ $\mathrm{NaC}_{2} \mathrm{H}_{3} \mathrm{O}_{2}, 2.0 \mathrm{~g}$ yeast extract, $2.0 \mathrm{~g}$ bio-Trypticase, $1 \mathrm{mg}$ resazurin and $10.0 \mathrm{ml}$ trace mineral element solution (Balch et al., 1979) was used for isolation and routine cultivation. The $\mathrm{pH}$ of the medium was adjusted to 7.5 with $1 \mathrm{M} \mathrm{KOH}$ at ambient temperature before sterilization (Ravot et al., 1995).

The medium was boiled under a stream of $\mathrm{O}_{2}$-free $\mathrm{N}_{2}$ gas and aliquots of $6 \mathrm{ml}$ and $10 \mathrm{ml}$ were dispensed anaerobically into $10 \mathrm{ml}$ and $60 \mathrm{ml}$ serum bottles, respectively. The bottles were then sealed and autoclaved for $21 \mathrm{~min}$ at $121{ }^{\circ} \mathrm{C}$. Prior to inoculation, $0.1 \mathrm{ml} \mathrm{Na} \mathrm{Na}_{2} \mathrm{~S} 9 \mathrm{H}_{2} \mathrm{O}$ from a $2 \%$ sterile anaerobic solution, $0.1 \mathrm{ml} \mathrm{Na}_{2} \mathrm{CO}_{3}$ from a $10 \%$ anaerobic solution and $0.1 \mathrm{ml} 20 \mathrm{mM}$ filter-sterilized $\mathrm{Na}_{2} \mathrm{~S}_{2} \mathrm{O}_{3}$ were injected separately by syringe.

Formation fluid samples $(0.1 \mathrm{ml})$ were inoculated into the anaerobic basal medium described above. All serum bottles were incubated at $40{ }^{\circ} \mathrm{C}$ for $3-5$ days depending on 
growth. Subculturing was conducted in the same medium after 3 days of incubation. All the subcultures were incubated at $40{ }^{\circ} \mathrm{C}$ under atmospheric pressure. Three days after incubation, the first sets of subcultures were serially diluted using fresh anaerobic basal medium and $10 \mu \mathrm{l}$ aliquots of the serially diluted culture $\left(10^{-7}\right.$ and $10^{-8}$ dilutions) were streaked on the same basal medium that had been solidified with $1.2 \%$ agar. All the culture plates were incubated at $40{ }^{\circ} \mathrm{C}$ in an anaerobic chamber $\left(\mathrm{N}_{2}: \mathrm{H}_{2}: \mathrm{CO}_{2} ; 90: 5: 5\right)$ for 2-4 days until colonies appeared. Well-isolated colonies were transferred anaerobically to the liquid basal medium and incubated as described above. The plating and single colony isolation procedure was repeated several times until a pure culture of strain OCT $74^{\mathrm{T}}$ was obtained. Gram-staining was routinely performed and the purity of the cultures was examined under a light microscope (AX 10, Carl Zeiss). Light microscopic examinations revealed the presence of rodshaped bacteria with an outer sheath-like structure (toga) and a Gram-negative appearance. The morphology of strain OCT $74^{\mathrm{T}}$ was examined further by transmission electron microscopy (Morgagni-268D, Fei). Cells were negatively stained as described previously (Zillig et al., 1990).

Cells of strain OCT74 ${ }^{\mathrm{T}}$ were rod-shaped with a diameter of $0.5-0.7 \mu \mathrm{m}$ and length of $1.5-1.7 \mu \mathrm{m}$ (Fig. 1a). Cells occurred singly, in pairs and in short irregularly curved chains surrounded by the outer sheath-like structure, or toga, that is specific to members of the order Thermotogales. The number of cells in the chains varied depending on the culture conditions. Cells were Gramnegative in appearance in all the growth phases. The cell envelope was clearly visible by TEM in cells at all phases of growth. In addition, TEM images revealed the presence of multiple flagella (Fig. 1a, b). In the stationary growth phase, the cells became short rods or spheres surrounded by a sheath (Fig. 1c). Cells were capable of multiplying within the sheath and formed enlarged structures. Spores were not observed.
Substrate utilization tests were performed in anaerobically prepared MMS medium (Huber et al., 1986) containing $\left(\mathrm{l}^{-1}\right): 6.93 \mathrm{~g} \mathrm{NaCl}, 1.75 \mathrm{~g} \mathrm{MgSO}_{4} .7 \mathrm{H}_{2} \mathrm{O}, 1.38 \mathrm{~g}$ $\mathrm{MgCl}_{2} \cdot 6 \mathrm{H}_{2} \mathrm{O}, 0.16 \mathrm{~g} \mathrm{KCl}, 25 \mathrm{mg} \mathrm{NaBr}, 7.5 \mathrm{mg} \mathrm{H} \mathrm{BO}_{3}$, $3.8 \mathrm{mg} \mathrm{SrCl}{ }_{2} .6 \mathrm{H}_{2} \mathrm{O}, 0.38 \mathrm{~g} \mathrm{CaCl}_{2}, 0.5 \mathrm{~g} \mathrm{KH}_{2} \mathrm{PO}_{4}, 0.5 \mathrm{~g}$ $\mathrm{Na}_{2} \mathrm{~S}, 2 \mathrm{mg}(\mathrm{NH} 4)_{2} \mathrm{Ni}\left(\mathrm{SO}_{4}\right)_{2}, 15 \mathrm{ml}$ trace minerals (Balch et al., 1979) and $1 \mathrm{mg}$ resazurin. The following substrates were tested at a final concentration of $20 \mathrm{mM}$ : glucose, fructose, ribose, rhamnose, raffinose, arabinose, maltose, cellobiose, cellulose, pectin, xylan, xylose, starch, sorbitol, formate, acetate and ethanol. Growth of the strain on acetate, ethanol and formate was tested in the presence of thiosulfate and elemental sulfur. The following proteinaceous substances were also tested at $0.2 \%(\mathrm{w} / \mathrm{v})$ : yeast extract, brain-heart infusion, peptone, tryptone and casein. The $\mathrm{pH}$ of the medium was adjusted to 7.5 with $1 \mathrm{M}$ $\mathrm{NaOH}$. All substrate utilization studies were performed in triplicate using $60 \mathrm{ml}$ serum bottles containing $10 \mathrm{ml}$ MMS medium. Bacterial growth and substrate utilization were determined by viable colony counts on solid medium and by monitoring the turbidity at $\mathrm{OD}_{600}$ by spectrometry (UV-2450, Shimadzu). Positive cultures were confirmed by subculturing on the same basal medium.

Strain OCT74 ${ }^{\mathrm{T}}$ possessed a chemo-organotrophic metabolism and was able to grow on the following substances: glucose, fructose, cellobiose, arabinose, raffinose, rhamnose, sucrose, xylose, ribose, starch, ethanol, formate, acetate, brain heart infusion, yeast extract and bioTrypticase. Growth was not observed in cultures with lactose, maltose, pectin, sorbitol or casein added. Growth on carbohydrates was found to be stimulated by yeast extract.

The temperature range for growth and the tolerance of different $\mathrm{NaCl}$ concentrations were determined in liquid MMS medium supplemented with $20 \mathrm{mM}$ glucose. The $\mathrm{pH}$ of the medium was adjusted to $\mathrm{pH}$ 7.5. The requirement for $\mathrm{NaCl}$ for growth was tested in liquid MMS medium containing $0,0.05,0.5,1,2,3,4,5,7,10$ and $12 \% \mathrm{NaCl}$ $(\mathrm{w} / \mathrm{v})$. Tolerance to $\mathrm{NaCl}$ was studied using a modified
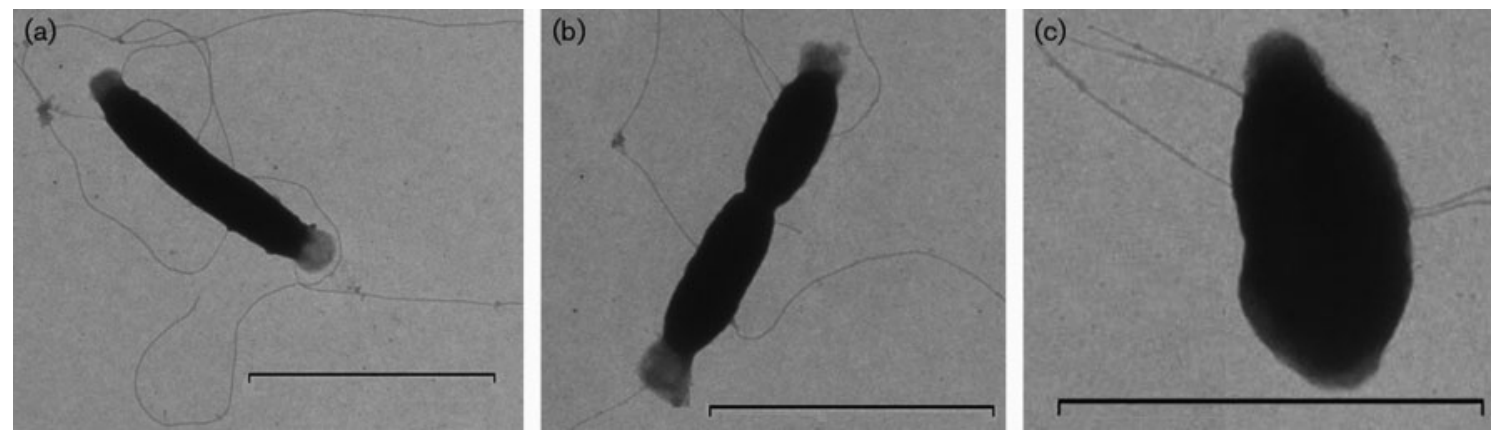

Fig. 1. (a-b), TEM images of negatively stained rod-shaped cells surrounded by a sheath-like structure or 'toga' in the midexponential phase of growth. (c), TEM image of a negatively stained spherically shaped cell in the stationary phase of growth. Bars, $2 \mu \mathrm{m}$. 
MMS medium in which $\mathrm{NaHCO}_{3}$ was replaced with $\mathrm{K}_{2} \mathrm{CO}_{3}$ and $\mathrm{Na}_{2} \mathrm{~S}$ was replaced with $\mathrm{K}_{2} \mathrm{~S}$. The $\mathrm{pH}$ range for growth was studied in liquid MMS medium. The $\mathrm{pH}$ of the medium was adjusted to different $\mathrm{pH}$ values ranging from 4.5 to 9.5 with $1 \mathrm{M} \mathrm{HCl}$ or $1 \mathrm{M} \mathrm{KOH}$.

Strain OCT $74^{\mathrm{T}}$ grew anaerobically and growth occurred from 25 to $70{ }^{\circ} \mathrm{C}$. However, weak growth was observed at $70{ }^{\circ} \mathrm{C}$. The strain was readily adaptable to mesophilic growth $\left(37^{\circ} \mathrm{C}\right)$ after several subculturing steps under mesophilic conditions. Growth of strain OCT74 ${ }^{\mathrm{T}}$ was observed within the $\mathrm{pH}$ range 5.5-9.0 with an optimum $\mathrm{pH}$ for growth of 7.3-7.8. Strain OCT74 ${ }^{\mathrm{T}}$ grew within the $\mathrm{NaCl}$ concentration range of $0-12 \%$ with an optimum of 4.0 $4.5 \%$. Under optimal growth conditions, growth of the novel strain at high concentrations of $\mathrm{NaCl}(>7 \%)$ varied according to the carbon source used. Weaker growth was observed at $10-12 \%(\mathrm{w} / \mathrm{v}) \mathrm{NaCl}$ even in the presence of preferred carbon sources such as fructose or dextrin. Under optimal conditions, the doubling time for strain OCT74 ${ }^{\mathrm{T}}$ was about $1.6 \mathrm{~h}^{-1}$ in MMS medium with glucose as the sole carbon source.

The utilization of various electron acceptors was studied in liquid MMS medium containing $3 \mathrm{~g}$ glucose $1^{-1}$ as the electron donor. Cultures grown in pre-reduced MMS medium without added electron acceptor were used as inocula $(5 \% \mathrm{v} / \mathrm{v})$. Electron acceptors were added to the medium in the form of filter-sterilized $(0.2 \mu \mathrm{m}$, Millipore $)$ or autoclaved stock solutions. The final concentrations of the electron acceptors $\left(\mathrm{FeSO}_{4}, \mathrm{NH}_{4} \mathrm{SO}_{4}, \mathrm{KNO}_{3}\right.$ and $\left.\mathrm{Na}_{2} \mathrm{~S}_{2} \mathrm{O}_{3}\right)$ were $20 \mathrm{mM}$. Elemental sulfur $(50 \mathrm{mg})$ was added to individual serum bottles containing $10 \mathrm{ml}$ liquid basal medium prior to autoclaving.

Hydrogen sulfide production was detected colorimetrically using a spectrophotometer (U2000, Hitachi) at $600 \mathrm{~nm}$ using a sulfide detection kit (Merck) according to the manufacturer's instructions. Strain OCT $74^{\mathrm{T}}$ could utilize sodium thiosulfate and elementary sulfur as electron acceptors, which resulted in the production of hydrogen sulfide. The addition of elemental sulfur could support the growth of the strain OCT $74^{\mathrm{T}}$. Thiosulfate and sulfur were both reported to improve the growth rates or cell yields for Fervidobacterium islandicum, Thermotoga maritima, Thermotoga neapolitana, Thermosipho africanus and Thermotoga elfii (Ravot et al., 1995). However, in the case of Marinitoga camini, neither sulfur nor thiosulfate had a major stimulatory effect on growth rates and final cell concentrations (Wery et al., 2001). For strain OCT74 ${ }^{\mathrm{T}}$, Lcystine hydrochloride did not support growth and growth was suppressed by higher concentrations of this substance.

The end products of glucose metabolism in the liquid phase were determined by GC using a machine (GC6890N, Agilent) equipped with a flame-ionization detector and a DB-WAXetr column $(30 \mathrm{~m} \times 530 \mu \mathrm{m} \times 1 \mu \mathrm{m})$. The oven temperature was $140{ }^{\circ} \mathrm{C}$ and the temperature ramping was $1{ }^{\circ} \mathrm{C} \min ^{-1}$ up to $158{ }^{\circ} \mathrm{C}$. The injector and detector temperatures were $220{ }^{\circ} \mathrm{C}$ and $230{ }^{\circ} \mathrm{C}$, respectively. Helium was used as the carrier gas. Ethanol was detected by HPLC using a machine (1100 series, Agilent) equipped with a Sugar-Pak I column (Water Research). The composition of the headspace gases from the cultures was directly measured by GC with a GC6890N (Agilent) machine equipped with a thermal conductivity detector and a HPPLOT Q column $(15 \mathrm{~m} \times 530 \mu \mathrm{m} \times 40 \mu \mathrm{m})$. The oven, injector and detector temperatures were 40,60 and $250{ }^{\circ} \mathrm{C}$, respectively, and nitrogen was used as the carrier gas. The major end products of glucose fermentation were acetate, $\mathrm{CO}_{2}$ and $\mathrm{H}_{2}$ with minor production of ethanol.

Identification and quantification of fatty acid methyl esters was performed using the Sherlock Microbial Identification System (MIS) from MIDI Inc. (USA). The assay was conducted twice. The major fatty acids detected in cell extracts of strain OCT74 ${ }^{\mathrm{T}}$ were $\mathrm{C}_{16: 0}, \mathrm{C}_{17: 0}$ cyclopropane, $\mathrm{C}_{16: 1} \omega 7 c, \mathrm{C}_{18: 1} \omega 7 c, \mathrm{C}_{14: 0}, \mathrm{C}_{16: 0} 3-\mathrm{OH}$ (Table 1).

Antibiotic susceptibility tests were performed with anaerobic filter-sterilized stocks of rifamycin, vancomycin,

Table 1. Fatty acid contents (\%) of strain OCT $74^{\top}$

tr, Trace $(<0.1 \%)$. The data presented in the table are the means from two independent experiments.

\begin{tabular}{|c|c|}
\hline Fatty acid & Total (\%) \\
\hline $\mathrm{C}_{10: 0} 3-\mathrm{OH}$ & 0.2 \\
\hline $\mathrm{C}_{12: 0}$ & 0.3 \\
\hline $\mathrm{C}_{14: 0}$ & 5.6 \\
\hline $\mathrm{C}_{14: 0}$ DMA & $\operatorname{tr}$ \\
\hline $\mathrm{C}_{15: 1} \omega 5 c$ & 0.2 \\
\hline $\mathrm{C}_{15: 0}$ & 0.5 \\
\hline $\mathrm{C}_{16: 1} \omega 7 c$ & 8.5 \\
\hline $\mathrm{C}_{16: 1} \omega 5 c$ & 0.6 \\
\hline $\mathrm{C}_{16: 0}$ & 27.5 \\
\hline $\mathrm{C}_{15: 0} 3-\mathrm{OH}$ & 0.3 \\
\hline $\mathrm{C}_{17: 0}$ cyclopropane & 14.0 \\
\hline $\mathrm{C}_{17: 0}$ & 1.1 \\
\hline $\mathrm{C}_{16: 0} 2-\mathrm{OH}$ & 2.0 \\
\hline $\mathrm{C}_{16: 0} 3-\mathrm{OH}$ & 5.7 \\
\hline $\mathrm{C}_{18: 1} \omega 5 c$ & 0.4 \\
\hline $\mathrm{C}_{18: 0}$ & 1.0 \\
\hline Unknown $^{\star}$ & 17.8 \\
\hline \multicolumn{2}{|l|}{ Summed features $\dagger$} \\
\hline 1 & 0.6 \\
\hline 2 & 0.3 \\
\hline 5 & 5.9 \\
\hline 10 & 15.8 \\
\hline 13 & 0.3 \\
\hline
\end{tabular}

${ }^{*}$ Unknown fatty acids; these compounds have no names listed in the Peak Library File of the MIDI system and are therefore not identified. $\dagger$ Summed features represent fatty acids that cannot be separated by the Microbial Identification System. Summed feature 1 consisted of $\mathrm{C}_{14: 0}$ aldehyde; summed feature 2 consisted of $\mathrm{C}_{12: 0} 3-\mathrm{OH}$; summed feature 5 consisted of $\mathrm{C}_{14: 0} 3-\mathrm{OH}$; summed feature 10 consisted of $\mathrm{C}_{18: 1} \omega 7 c$; summed feature 13 consisted of $\mathrm{C}_{14: 0} 2-\mathrm{OH}$. 
chloramphenicol, kanamycin (each at final concentrations of 10 and $100 \mu \mathrm{g} \mathrm{ml}^{-1}$ ). Growth was inhibited by spectinomycin, rifamycin and chloramphenicol at $25 \mu \mathrm{g} \mathrm{ml} l^{-1}$. The strain was sensitive to vancomycin at $100 \mu \mathrm{g} \mathrm{ml}^{-1}$. Growth of strain OCT $74^{\mathrm{T}}$ was inhibited at kanamycin concentrations of $250 \mu \mathrm{g} \mathrm{ml}^{-1}$.

Genomic DNA was isolated by a standard phenol/ chloroform extraction followed by ethanol precipitation (Sambrook et al., 1989). The DNA base composition was determined using the HPLC technique (Mesbah et al., 1989). The $\mathrm{G}+\mathrm{C}$ content of the genomic DNA of the strain OCT74 ${ }^{\mathrm{T}}$ was determined as $26.8 \mathrm{~mol} \%$.

The 16S rRNA gene of strain OCT74 ${ }^{\mathrm{T}}$ was amplified by PCR using MicroSec Full Gene kit (Applied Biosystems) according to the manufacturer's instructions. The amplified fragment was extracted from a $1.5 \%$ agarose gel using the Qiagen Gel extraction kit (Qiagen). Purified PCR products were sequenced using the DyeDeoxy Terminator Cycle sequencing kit (Applied Biosystems) as directed in the manufacturer's protocol with an automatic DNA sequencer (model 310 ABI PRISM, Applied Biosystems).

To ascertain the phylogenetic position of the novel strain, the 16S rRNA gene sequence of strain OCT74 ${ }^{\mathrm{T}}$ was compared with the most similar sequences available in GenBank using the BLAST programme (Altschul et al., 1997). A BLAST search against the GenBank database revealed that strain OCT74 $4^{\mathrm{T}}$ belonged to the order Thermotogales. Consequently, the $16 \mathrm{~S}$ rRNA gene sequence of strain $\mathrm{OCT} 74^{\mathrm{T}}$ was aligned with closely related sequences and those of representatives of the other genera of the order Thermotogales that were retrieved from GenBank using CLUstal W (Thompson et al., 1994). Pairwise evolutionary distances were computed using the Jukes-Cantor model (Jukes \& Cantor, 1969). Phylogenetic analyses were performed using PHYLIP version 3.67 (Felsenstein, 2007) and an unrooted phylogenetic tree was constructed using the neighbour-joining algorithm (Saitou \& Nei, 1987). Confidence in the tree topologies was evaluated by bootstrap analysis (Felsenstein, 1985) based on 100 resamplings.

Of the genera within the order Thermotogales, strain OCT74 ${ }^{\mathrm{T}}$ was closest to the genera Geotoga, Petrotoga and Marinitoga. The sequence of strain OCT74 ${ }^{\mathrm{T}}$ grouped with the Geotoga, Petrotoga and Marinitoga lineage with all three algorithms used (neighbour-joining, maximum-parsimony and maximum-likelihood). However, within this lineage, strain OCT $74^{\mathrm{T}}$ represented a distinct branching line (Fig. 2).

The level of $16 \mathrm{~S}$ rRNA gene sequence similarity between strain OCT $74^{\mathrm{T}}$ and recognized members of the related genera was less than $88 \%$ in all the cases. The highest $16 \mathrm{~S}$ rRNA gene sequence similarity $(88 \%)$ was to Geotoga petraea and Geotoga subterranea. Similarity

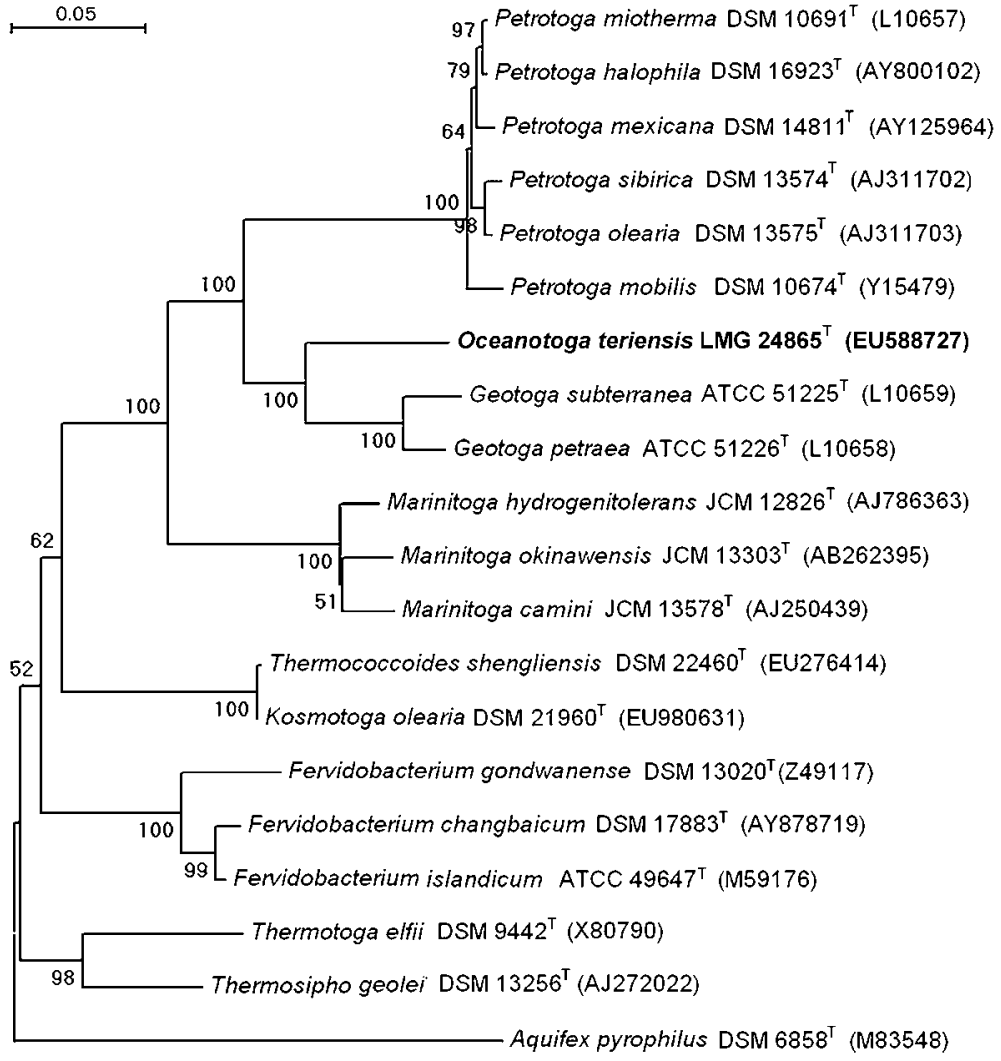

Fig. 2. $16 \mathrm{~S}$ rRNA gene sequence-based phylogenetic distance-analysis dendrogram indicating the position of strain OCT $74^{\top}$ among closely related members of the order Thermotogales. Numbers at branching points refer to bootstrap values. The position of the root was determined by including Aquifex pyrophilus as the outgroup. Bar, 0.05 substitutions per nucleotide position. 
values between 80 and $84 \%$ were found between strain OCT74 ${ }^{\mathrm{T}}$ and members of the genera Petrotoga and Marinitoga.

Strain OCT $74^{\mathrm{T}}$ was isolated from formation fluid samples collected from offshore oil-producing well heads. The oil wells were repeatedly flooded with seawater for secondary oil recovery and so the formation fluid was partly mixed with seawater. Given that strain OCT $74^{\mathrm{T}}$ was tolerant to a wide range of salinities, it could have originated from seawater. The novel strain was moderately thermophilic, but could be readily adapted to mesophilic growth conditions after several subculturing steps under mesophilic conditions $\left(37^{\circ} \mathrm{C}\right)$. The closest phylogenetic neighbours to strain $\mathrm{OCT}^{\mathrm{T}} 4^{\mathrm{T}}$, based on 16S rRNA gene sequence analysis, were G. petraea and G. subterranea, but these strains showed around $12 \%$ sequence divergence from the novel strain. In addition to distinct phylogenetic and genomic differences between strain OCT $74^{\mathrm{T}}$ and species of the genus Geotoga, several differential phenotypic characteristics were also found. Unlike members of the genus Geotoga, strain OCT74 ${ }^{\mathrm{T}}$ was able to grow with $0 \% \mathrm{NaCl}$ (Davey et al., 1993). Further, in contrast to species of the genus Geotoga, strain OCT $74^{\mathrm{T}}$ was able to utilize xylose, raffinose, acetate, formate and ethanol (weak growth) as sole carbon sources. Yeast extract supported the growth of strain OCT74 ${ }^{\mathrm{T}}$. Cells of the novel strain were able to grow and replicate within the sheath and formed rotund bodies as described for Fervidobacterium nodosum. This characteristic has not been reported for members of the genera Geotoga, Petrotoga or Marinitoga (Davey et al., 1993).

The 16S rRNA gene sequence divergence of strain OCT $74^{\mathrm{T}}$ with members of the genera Petrotoga and Marinitoga was $>15 \%$. Therefore, phenotypic comparisons with recognized species of these genera were not performed. As shown in Table 2, numerous phenotypic differences were found between strain OCT $74^{\mathrm{T}}$ and other members of the genera of the order Thermotogales. In addition, strain OCT $74^{\mathrm{T}}$ was distinctly different from members of genus Fervidobacterium, which produce spheroids due to the protrusion of the outer cell wall (Patel et al., 1985). Strain OCT $74^{\mathrm{T}}$ had a low optimum temperature for growth and so could be distinguished from members of the genera Thermotoga, Fervidobacterium and Thermosipho, which have much higher optimum temperatures (above $60{ }^{\circ} \mathrm{C}$ ) for growth (Huber et al., 1986, 1989; Patel et al., 1985). Moreover, the DNA G $+\mathrm{C}$ content of strain OCT $74^{\mathrm{T}}$ was $26.8 \mathrm{~mol} \%$, which was lower than those of G. petraea and G. subterranea (30 mol\%), Petrotoga miotherma (40 mol\%), members of the genus Thermotoga (40$46 \mathrm{~mol} \%), \quad F$. islandicum (40 mol\%) and Thermosipho africanus (30 mol\%). Unlike species of the genus Petrotoga, which are described as fermentative bacteria able to grow on various polysaccharides, strain OCT74 ${ }^{\mathrm{T}}$ was able to grow on both sugars and complex proteinaceous substances such as yeast extract, peptone, tryptone and brain-heart infusion.
Based on comparative morphological, physiological and genomic data, it is concluded that strain OCT74 ${ }^{\mathrm{T}}$ represents a novel species of a new genus, for which the name Oceanotoga teriensis gen. nov., sp. nov. is proposed.

\section{Description of Oceanotoga gen. nov.}

Oceanotoga (O.ce.a.no.to'ga. Gr. n. okeanos the ocean; L. fem. n. toga a covering, garment; N.L. fem. n. Oceanotoga an ocean toga, referring to the isolation of the organism from the ocean and the presence of a 'toga' sheath-like outer cover).

Cells are rod-shaped with a sheath-like outer structure. Cells occur singly, in pairs or in chains. Cells are Gramnegative, no spores are formed. During the stationary phase of growth, the rods form spherical structures that are still surrounded by the sheath. Growth is anaerobic, moderately thermophilic and moderately halophilic. Chemo-organotrophic and able to ferment a broad spectrum of carbohydrates and various proteinaceous substances. Able to reduce thiosulfate and elemental sulphur to $\mathrm{H}_{2} \mathrm{~S}$, but these compounds are not essential for growth. The DNA G $+\mathrm{C}$ content of the type strain of the type species is $26.8 \mathrm{~mol} \%$. The $16 \mathrm{~S}$ rRNA gene sequence comparisons place the genus Oceanotoga in the bacterial domain within the order Thermotogales, close to the Geotoga lineage. The type species is Oceanotoga teriensis.

\section{Description of Oceanotoga teriensis sp. nov.}

Oceanotoga teriensis [te.ri.en'sis. N.L. fem. adj. teriensis pertaining to TERI, named in honour of The Energy and Resource Institute (TERI), New Delhi, India].

Has the following characteristics in addition to those given in the genus description. Under optimum conditions, cells appear as short rods $(2-3 \mu \mathrm{m}$ long $\times 0.5-1 \mu \mathrm{m}$ wide $)$ and form pairs or chains. The length of the chains is variable. Cells are motile with multiple flagella. No spores are formed. Growth occurs between 25 and $70{ }^{\circ} \mathrm{C}$ (optimum, $55-58{ }^{\circ} \mathrm{C}$ ), at $\mathrm{pH}$ values between $\mathrm{pH} 5.5$ and 9.0 (optimum, $\mathrm{pH} 7.3-7.8$ ) and $\mathrm{NaCl}$ concentrations between 0 and $12 \%(\mathrm{w} / \mathrm{v})$ (optimum $4.0-4.5 \% \mathrm{NaCl})$. The doubling time under optimal conditions is approximately $1.6 \mathrm{~h}$. Chemo-organotrophic and able to grow on glucose, fructose, starch, cellobiose, arabinose, raffinose, xylan, rhamnose, sucrose, xylose, ribose and complex proteinaceous substances such as brain-heart infusion, bioTrypticase and peptone in the presence of yeast extract. Reduces thiosulfate and elemental sulfur to sulfide. The end products of glucose fermentation are $\mathrm{H}_{2}, \mathrm{CO}_{2}$ and acetic acid. The $16 \mathrm{~S}$ rRNA gene sequence similarity to $G$. petraea and G. subterranea is approx. $88 \%$.

The type strain, OCT74 ${ }^{\mathrm{T}}\left(=\mathrm{JCM} 15580^{\mathrm{T}}=\right.$ LMG $\left.24865^{\mathrm{T}}\right)$, was isolated from oil-producing well heads located at Bombay High, Western India. The DNA G $+\mathrm{C}$ content of the type strain is $26.8 \mathrm{~mol} \%$. 
Table 2. Differential characteristics between strain OCT $74^{\top}$ and related genera of the order Thermotogales

Taxa: 1, OCT74 ${ }^{\mathrm{T}}$ (data from this study); 2, G. subterranea ATCC $51225^{\mathrm{T}}$; 3, G. petraea ATCC $51226^{\mathrm{T}}$ (data from Davey et al., 1993); 4, P. miotherma ATCC 51224 ${ }^{\mathrm{T}}$ (Davey et al., 1993); 5, M. camini DSM 13578 ${ }^{\mathrm{T}}$ (Wery et al., 2001); 6, F. nodosum ATCC 35602 ${ }^{\mathrm{T}}$ (Patel et al., 1985); 7, Thermotoga maritima DSM $3109^{\mathrm{T}}$ (Huber et al., 1986). NR, not reported; +, utilized; -, not utilized; +/-, variable.

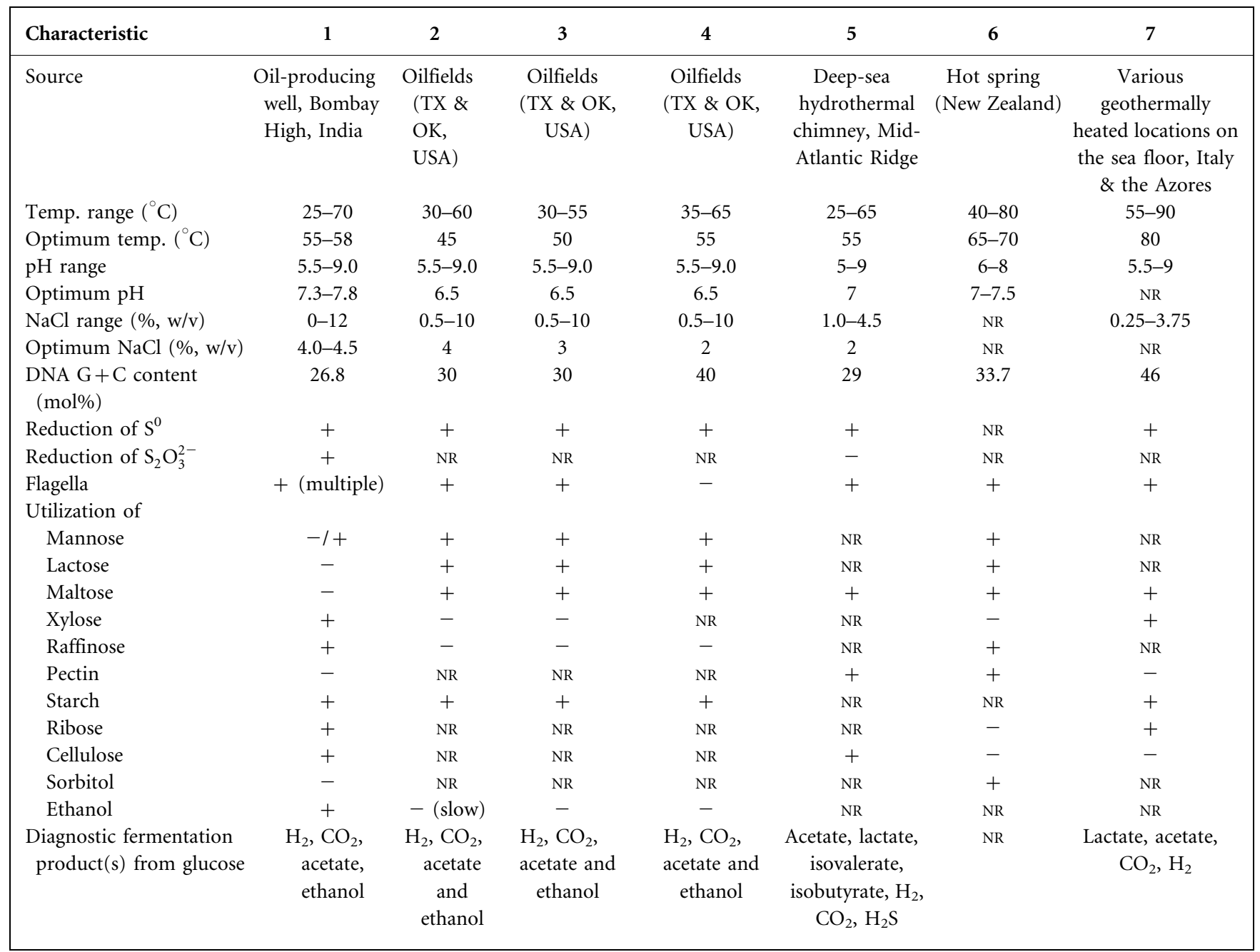

\section{Acknowledgements}

We are indebted to the Corporate Health Safety Environment of Oil and Natural Gas Corporation for financial support of this study and also Department of Biotechnology, Govt. of India for partial support. The authors are thankful to Dr R. K. Pachauri, DG, TERI, New Delhi, India, for providing the infrastructure facilities necessary for the present study. We thank Abu Swealsh, Laboratory technician, Microbial Biotechnology Division, TERI, for the collection of samples.

\section{References}

Alain, K., Marteinsson, V. T., Miroshnichenko, M. L., Bonch Osmolovskaya, E. A., Prieur, D. \& Birrien, J. L. (2002). Marinitoga piezophila sp. nov., a rod-shaped, thermo-piezophilic bacterium isolated under high hydrostatic pressure from a deep-sea hydrothermal vent. Int J Syst Evol Microbiol 52, 1331-1339.

Altschul, S. F., Madden, T. L., Schäffer, A. A., Zhang, J., Zhang, Z., Miller, W. \& Lipman, D. J. (1997). Gapped BLAST and PSI-BLAST: a new generation of protein database search programs. Nucleic Acids Res 25, 3389-3402.
Balch, W. E., Fox, G. E., Magrum, L. J., Woese, C. R. \& Wolfe, R. S. (1979). Methanogens: reevaluation of a unique biological group. Microbiol Rev 43, 260-296.

Bhupathiraju, V. K., McInerney, M. L. \& Knapp, R. (1993). Pretest studies for a microbially enhanced oil recovery field pilot in a hypersaline oil reservoir. Geomicrobiol J 11, 19-34.

Davey, M. E., Wood, W. A., Key, R., Nakamura, K. \& Stahi, D. (1993). Isolation three species of Geotoga and Petrotoga: Two new genera representing a new lineage in the bacterial line of descent distantly related to the "Thermotogales". Syst Appl Microbiol 16, 191-200.

DiPippo, J. L., Nesbø, C. L., Dahle, H., Doolittle, W. F., Birkland, N.-K. \& Noll, K. M. (2009). Kosmotoga olearia gen. nov., sp. nov., a thermophilic, anaerobic heterotroph isolated from an oil production fluid. Int J Syst Evol Microbiol 59, 2991-3000.

Fardeau, M.-L., Ollivier, B., Patel, B. K. C., Magot, M., Thomas, P., Rimbault, A., Rocchiccioli, F. \& Garcia, J.-L. (1997). Thermotoga hypogea sp. nov., a xylanolytic, thermophilic bacterium from an oil-producing well. Int J Syst Bacteriol 47, 1013-1019. 
Felsenstein, J. (1985). Confidence limits on phylogenies: an approach using the bootstrap. Evolution 39, 783-791.

Felsenstein, J. (2007). PHYLIP (Phylogeny Inference Package) version 3.67. Department of Genome Sciences, University of Washington, Seattle.

Feng, Y., Cheng, L., Zhang, X., Li, X., Deng, Y. \& Zhang, H. (2010). Thermococcoides shengliensis gen. nov., sp. nov., a new member of the order Thermotogales isolated from oil-production fluid. Int J Syst Evol Microbiol 60, 932-937.

Huber, R. \& Stetter, K. O. (1992). The Thermotogales: hyperthermophilic and extremely thermophilic bacteria. In Thermophilic bacteria, pp. 186-194. Edited by J. K. Kristjansson. Boca Raton, FL: CRC Press.

Huber, R., Langworthy, T. A., Konig, H., Thomn, M., Woese, C. R., Steytr, U. B. \& Stetter, K. O. (1986). Thermotoga maritima sp. nov. represents a new genus of uniquely extremely thermophilic eubacteria growing up to $90{ }^{\circ} \mathrm{C}$. Arch Microbiol 144, 324-333.

Huber, R., Woese, C. R., Langworthy, T. A., Fricke, H. \& Stetter, K. O. (1989). Thermosipho africanus gen. nov., represents a new genus of thermophilic eubacteria within the "Thermotogales". Syst J Appl Microbiol 12, 32-57.

Jukes, T. H. \& Cantor, C. R. (1969). Evolution of protein molecules. In Mammalian Protein Metabolism, pp. 211-232. Edited by $\mathrm{H}$. N. Munro. New York: Academic Press.

Mesbah, M., Premachandran, U. \& Whitman, W. B. (1989). Precise measurement of the $\mathrm{G}+\mathrm{C}$ content of deoxyribonucleic acid by high performance liquid chromatography. Int J Syst Evol Microbiol 39, $159-167$.

Nunoura, T., Oida, H., Miyazaki, M., Suzuki, Y., Takai, K. \& Horikoshi, K. (2007). Marinitoga okinawensis sp. nov., a novel thermophilic and anaerobic heterotroph isolated from a deep-sea hydrothermal field, Southern Okinawa Trough. Int J Syst Evol Microbiol 57, 467-471.

Patel, B. K. C., Morgan, H. W. \& Daniel, R. M. (1985). Fervidobacterium nodosum gen. nov. and spec. nov., a new chemoorganotrophic, caldoactive, anaerobic bacterium. Arch Microbiol 141, 6369.

Ravot, G., Ollivier, B., Magot, M., Patel, B. K. C., Crolet, J.-L., Fardeau, M.-L. \& Garcia, J.-L. (1995). Thiosulfate reduction, an important physiological feature shared by members of the order Thermotogales. Appl Environ Microbiol 61, 2053-2055.

Saitou, N. \& Nei, M. (1987). The neighbour-joining method: a new method for reconstructing phylogenetic trees. Mol Biol Evol 4, 406425.

Sambrook, J., Fritsch, E. F. \& Maniatis, T. (1989). Molecular Cloning: a Laboratory Manual, 2nd edn. Cold Spring Harbor, NY: Cold Spring Harbor Laboratory.

Thompson, J. D., Higgins, D. G. \& Gibson, T. J. (1994). CLUSTAL W: improving the sensitivity of progressive multiple sequence alignment through sequence weighting, position-specific gap penalties and weight matrix choice. Nucleic Acids Res 22, 4673-4680.

Wery, N., Lesongeur, F., Pignet, P., Derennes, V., Cambon-Bonavita, M. A., Godfroy, A. \& Barbier, G. (2001). Marinitoga camini gen. nov., sp. nov., a rod-shaped bacterium belonging to the order Thermotogales, isolated from a deep-sea hydrothermal vent. Int J Syst Evol Microbiol 51, 495-504.

Zillig, W., Holz, I., Janekovic, D., Klenk, H. P., Imsel, E., Trent, J., Wunderl, S., Forjaz, V. H., Coutinho, R. \& Ferreira, T. (1990). Hyperthermus butylicus, a hyperthermophilic sulfur-reducing archaebacterium that ferments peptides. J Bacteriol 172, 3959-3965. 